Research Article

\title{
Study of Direct Bonding Ceramics with Metal Using Sn2La Solder
}

\author{
Roman Koleňák and Igor Kostolný \\ Faculty of Materials Science and Technology in Trnava, Slovak University of Technology in Bratislava, \\ Paulinska 16, 91724 Trnava, Slovakia \\ Correspondence should be addressed to Igor Kostolný; igor.kostolny@stuba.sk
}

Received 23 September 2015; Revised 26 October 2015; Accepted 2 November 2015

Academic Editor: Wei Zhou

Copyright (C) 2015 R. Koleňák and I. Kostolný. This is an open access article distributed under the Creative Commons Attribution License, which permits unrestricted use, distribution, and reproduction in any medium, provided the original work is properly cited.

\begin{abstract}
The aim of this research was to study the direct bonding of ceramic materials, mainly $\mathrm{Al}_{2} \mathrm{O}_{3}$ and selected metals, with primary attention given to $\mathrm{Cu}$ substrate. Soldering was performed with Sn-based solder alloyed with 2\% La. We found that the bond formation between $\mathrm{Sn} 2 \mathrm{La}$ solder and $\mathrm{Al}_{2} \mathrm{O}_{3}$ occurs at the activation of lanthanum phases in solder by ultrasound. Lanthanum in the solder becomes oxidised in air during the soldering process. However, due to ultrasonic activation, the lanthanum particles are distributed to the boundary with ceramic material. A uniformly thin layer containing La, $1.5 \mu \mathrm{m}$ in thickness, is formed on the boundary with $\mathrm{Al}_{2} \mathrm{O}_{3}$ material, ensuring both wetting and joint formation. The shear strength with $\mathrm{Al}_{2} \mathrm{O}_{3}$ ceramics is $7.5 \mathrm{MPa}$. Increased strength to $13.5 \mathrm{MPa}$ was observed with $\mathrm{SiC}$ ceramics.
\end{abstract}

\section{Introduction}

Sn-based solders are the most used solders in the electronic industry for surface mount technology and similar applications [1-3]. However, industrial production often requires also joining parts made of different material combinations such as ceramics/metal [4-6]. In soldering such joints, it is inevitable that the ceramic material is wetted with metallic solder.

Research is at present oriented toward direct bonding of ceramic materials by application of active solders [7-10]. This approach reduces the time required for joint fabrication, the hygiene of the working environment is improved, and the economy of production is also enhanced.

The direct bonding of copper with $\mathrm{Al}_{2} \mathrm{O}_{3}$ ceramics was established [11]. The joint was fabricated by ultrasonic soldering with application of $\mathrm{Zn} 14 \mathrm{Al}$ solder. High quality joints without visible defects were achieved at optimised soldering parameters. The highest shear strength of $\mathrm{Al}_{2} \mathrm{O}_{3} / \mathrm{Zn} 14 \mathrm{Al} / \mathrm{Cu}$ joint, $80 \mathrm{MPa}$, was achieved at a soldering temperature of $480^{\circ} \mathrm{C}$ and soldering time of $30 \mathrm{~s}$.

In another study [12], the direct soldering of $\mathrm{SiC}$ ceramics was performed with ultrasound assistance. The $\mathrm{SiC}$ ceramic substrates were soldered in air with Zn8.5AllMg solder at a temperature of $420^{\circ} \mathrm{C}$. The highest strength $(148.1 \mathrm{MPa})$ was achieved with ultrasound acting for $8 \mathrm{~s}$. A new amorphous layer 2 to $6 \mathrm{~nm}$ in thickness was formed in the interface between the solder and substrate. The strong bond between $\mathrm{SiC}$ substrate and $\mathrm{Zn}-\mathrm{Al}-\mathrm{Mg}$ solder is attributed to transfer of $\mathrm{SiO}_{2}$ mass to $\mathrm{Zn}-\mathrm{Al}-\mathrm{Mg}$ solder due to cavitation erosion.

The subject of study [13] was oriented to direct soldering of sapphire by ultrasound with application of Sn10Zn2Al solder. It was found that ultrasound supported the oxidation reaction between $\mathrm{Al}$ from the solder and sapphire substrate. A nanocrystalline layer of $\alpha-\mathrm{Al}_{2} \mathrm{O}_{3}$ (2 $\mathrm{nm}$ in thickness) was formed in the $\mathrm{Sn}-\mathrm{Zn}-\mathrm{Al} /$ sapphire interface at soldering in air. This layer allowed the bond formation. The shear strength of joints achieved 43 to $48 \mathrm{MPa}$, which is a relatively high value when compared to other joints of $\mathrm{Al}_{2} \mathrm{O}_{3}$ ceramics fabricated with active Sn solders with addition of Ti and/or lanthanides.

The work [14] deals with direct soldering of $\mathrm{Al}_{2} \mathrm{O}_{3}$ by use of an active $\mathrm{Sn}$ solder type $\mathrm{Sn} 3.5 \mathrm{Ag} 4 \mathrm{Ti}(\mathrm{Ce}, \mathrm{Ga})$. Soldering was performed in air at a temperature of $280^{\circ} \mathrm{C}$. Ultrasound with a frequency of $40 \mathrm{kHz}$ was employed for solder activation. The shear strength of $\mathrm{Al}_{2} \mathrm{O}_{3} / \mathrm{Sn}-\mathrm{AgTi} / \mathrm{Al}_{2} \mathrm{O}_{3}$ joint was $24 \mathrm{MPa}$. A reaction layer, $4-7 \mu \mathrm{m}$ in thickness, was formed on 
the interface of $\mathrm{Al}_{2} \mathrm{O}_{3} / \mathrm{Sn}$ - AgTi joint, formed with Ti oxides, mainly TiO. This layer ensured the wettability of $\mathrm{Al}_{2} \mathrm{O}_{3}$ ceramics.

The direct soldering of ITO (indium tin oxide) ceramics with a copper substrate, performed with the same $\mathrm{Sn} 3.5 \mathrm{Ag} 4 \mathrm{Ti}(\mathrm{Ce}, \mathrm{Ga})$ solder in air at temperature of $250^{\circ} \mathrm{C}$, was solved in work [15]. The molten solder was agitated by mechanical activation for $30 \mathrm{~s}$. Line scanning has shown that Ti was segregated in the boundary between the ceramics and solder. This new layer is responsible for bond formation. The shear strength of ITO/Cu joints was $3.4 \mathrm{MPa}$. The $\mathrm{Cu} / \mathrm{Cu}$ and ITO/ITO joints attained shear strengths of $14.3 \mathrm{MPa}$ and $6.8 \mathrm{MPa}$, respectively.

In work [16], the authors have dealt with soldering of $\mathrm{Al}_{2} \mathrm{O}_{3} / \mathrm{Al}_{2} \mathrm{O}_{3}$ and $\mathrm{Al}_{2} \mathrm{O}_{3} / \mathrm{Cu}$ at a temperature of $250^{\circ} \mathrm{C}$ in air. The molten Sn3.5Ag4Ti(Ce, Ga) solder was agitated for $30 \mathrm{~s}$ for wetting on bond surfaces and then a copper or alumina specimen was placed on the molten solder to be joined with an alumina specimen by rubbing together for $30 \mathrm{~s}$. The affinity of Ce to oxygen prevents $\mathrm{Ti}$ from oxidising and thus $\mathrm{Ti}$ can react with $\mathrm{Al}_{2} \mathrm{O}_{3}$ at a low temperature. The shear strength of alumina/alumina, copper/copper, and alumina/copper joints was $13.5 \mathrm{MPa}, 14.3 \mathrm{MPa}$, and $10.2 \mathrm{MPa}$, respectively.

In spite of a great number of positive properties, which Sn solder attains by the addition of rare earth elements to alloy, some negative phenomena also occurred, namely, the formation of Sn whiskers. A wide group of authors [1923] dealt with this issue. The growth of whiskers is, by the opinion of many authors, caused by the oxidation on solder surfaces and due also to internal stress. Author [24] stated that the stress induced by formation of intermetallic $\mathrm{Cu}_{6} \mathrm{Sn}_{5}$ compound forces the $\mathrm{Sn}$ atoms out of the outer surface oxide of Sn layer. By author [25], the growth of Sn whiskers is very slow in most cases. Regarding the fact that the rare earth elements have a high chemical potential and that they react much easier with oxygen, they thus enhance the growth of $S n$ whiskers in solders containing these elements.

As is obvious from the studies mentioned, the active element is an essential component of the solder, since it ensures wettability and bond formation between the metallic solder and ceramic material.

Many research works dealt with solder where titanium was used as an active element [26-29]. Active solders containing $\mathrm{Ti}$ (up to $4 \mathrm{wt} . \%$ ) and small trace amounts of lanthanides such as Ce [18, 30-32] were also studied. Cerium and other lanthanides in those solders contained around 0.1 to $0.2 \mathrm{wt} . \%$ in trace amounts. The authors in the mentioned works did not study whether the presence of lanthanides without the presence of Ti can ensure the wettability of ceramic substrates such as $\mathrm{Al}_{2} \mathrm{O}_{3}$ and thus create a direct bonding with the ceramic material.

The aim of our study was oriented toward the direct bonding of $\mathrm{Al}_{2} \mathrm{O}_{3}$ ceramics with copper substrate with the application of Sn2La solder. We studied whether Sn-based solder, alloyed with $\mathrm{La}$, can wet $\mathrm{Al}_{2} \mathrm{O}_{3}$ ceramics and form a strong bond. We also studied whether La can substitute Ti in the active Sn solders.

For this purpose, the analyses were performed to reveal the mechanism of bond formation and the shear strength

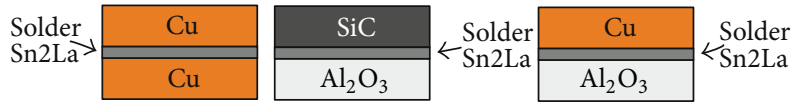

Figure 1: Analysed combinations of $\mathrm{Cu} / \mathrm{Cu}, \mathrm{SiC}_{\mathrm{Al}} \mathrm{O}_{2} \mathrm{O}_{3}$, and $\mathrm{Cu} /$ $\mathrm{Al}_{2} \mathrm{O}_{3}$ materials.

of fabricated joints was also measured. Lanthanum, which exerts a high affinity to oxygen, was applied as an active element in this case. The amount of $2 \mathrm{wt}$.\% La was selected for comparison, since in the previous study [26] we dealt with interactions of $\mathrm{Sn} 2 \mathrm{Ti}$ solder with the surface of $\mathrm{Al}_{2} \mathrm{O}_{3}$ ceramics. Soldering was performed at a low temperature in air with application of high-power ultrasound.

\section{Experimental}

Sn solder with 2 wt.\% La was used in the experiments. The solder was manufactured by casting in form of an ingot. Weighing single solder components was done after setting the weight ratio of prepared alloys. Components with high purity from $3 \mathrm{~N}$ to $5 \mathrm{~N}$ were used for solder fabrication. The manufacture was performed in horizontal tube vacuum furnace with resistance heating. The working temperature used during manufacture was $900^{\circ} \mathrm{C}$ and vacuum of $10^{-4} \mathrm{~Pa}$ was also employed. At this temperature, held up within the time of $20 \mathrm{~min}$, homogenization of soldering alloy took place. Cooling down in vacuum furnace was slow. The cooling rate was $14^{\circ} \mathrm{C} / \mathrm{min}$.

The substrates of the following materials were used in experiments:

(i) Metallic Cu substrate of $4 \mathrm{~N}$ purity in the shape of rings in dimensions $\Phi 15 \times 1.5 \mathrm{~mm}$.

(ii) Ceramic $\mathrm{Al}_{2} \mathrm{O}_{3}$ substrate of $5 \mathrm{~N}$ purity in the form of $\Phi 15 \times 2 \mathrm{~mm}$ rings (manufacturer Glynwed, $\mathrm{GmbH}$, designation Degussit Al23).

(iii) Ceramic SiC substrate in form of $\Phi 15 \times 3 \mathrm{~mm}$ rings (manufacturer CeramTec, $\mathrm{GmbH}$, designation Rocar $\mathrm{SiC})$.

For a more detailed analysis, the material combinations given in Figure 1 were selected.

Soldering was performed on Hanuz UT2 ultrasonic equipment with parameters given in Table 1 . Solder activation was realised by using an encapsulated ultrasonic transducer consisting of a piezoelectric oscillation system and titanium sonotrode with an end diameter of $\Phi 3 \mathrm{~mm}$. The scheme of ultrasonic soldering through the layer of molten solder is shown in Figure 2. The soldering temperature was $20^{\circ} \mathrm{C}$ above the liquid temperature of the solder. Soldering temperature was controlled by a continuous temperature measurement on hot $\mathrm{NiCr} / \mathrm{NiSi}$ plate by a thermocouple.

Soldering proceeded as follows: solder layer was deposited on the substrate heated at a soldering temperature. The liquid solder was then subjected to ultrasound activation in air for $5 \mathrm{~s}$. After ultrasonic activation, the excessive layer of molten solder and formed oxides were removed from 
TABLE 1: Soldering parameters.

\begin{tabular}{lcc}
\hline Ultrasound power & {$[\mathrm{W}]$} & 400 \\
Working frequency & {$[\mathrm{kHz}]$} & 40 \\
Amplitude & {$[\mu \mathrm{m}]$} & 2 \\
Soldering temperature & {$\left[{ }^{\circ} \mathrm{C}\right]$} & 290 \\
Time of ultrasound activation & {$[\mathrm{s}]$} & 5 \\
\hline
\end{tabular}

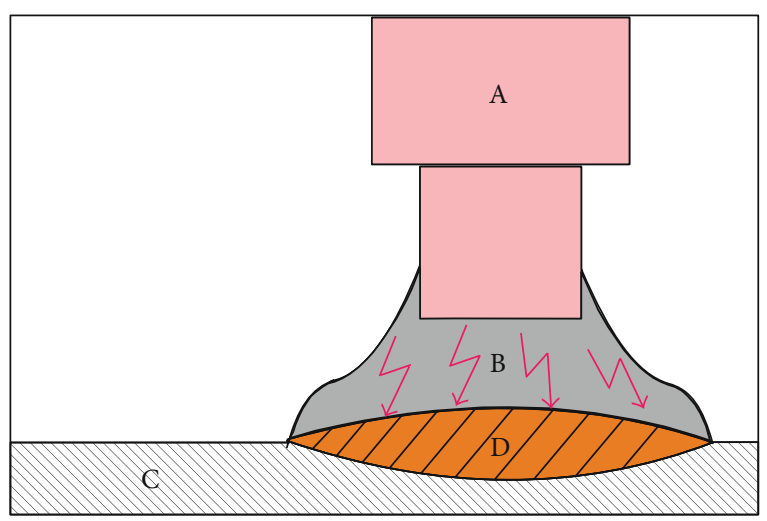
(A) Ultrasonic tool
(D) Reaction layer
(B) Solder
(C) Substrate
L. Ultrasonic wave

FIGURE 2: Ultrasonic soldering through the layer of molten solder.

the substrate surface. Both joined surfaces were prepared in this way. The substrates with deposited layer of molten solder were laid on each other to obtain contact with the liquid phase. Then, they were centred and the joint formed by their slight compression. Graphical representation of this procedure is shown in Figure 3.

Metallographic preparation of specimens from soldered joints was realised by the standard metallographic procedures. Grinding was performed by use of $\mathrm{SiC}$ emery papers with granularity of 240,320 , and 1200 grains $/ \mathrm{cm}^{2}$. Polishing was performed by use of diamond suspensions with grain sizes: $9 \mu \mathrm{m}, 6 \mu \mathrm{m}$, and $3 \mu \mathrm{m}$. Final polishing was made by use of polishing emulsion OP-S (Struers) with $0.2 \mu \mathrm{m}$ grain size.

Solder microstructure was studied using

(i) light optical microscope type Neophot 32 with the application of image analyser NIS-Elements, type E,

(ii) electron scanning microscopy (SEM) on FEI Quanta 200 FEG microscope,

(iii) qualitative and semiquantitative chemical analysis of Sn2La solder performed on JEOL $7600 \mathrm{~F}$ equipment with microanalyser type Microspec WDX-3PC.

$\mathrm{X}$-ray diffraction analysis was used for identification of phase composition of solder. It was realised with a solder specimen in dimensions of $10 \times 10 \mathrm{~mm}$ on XRD diffractometer type PANalytical X'Pert PRO.
DSC analysis of Sn2La solder was performed on equipment type Netzsch STA 409 C/CD in shielding with Ar gas of $6 \mathrm{~N}$ purity.

Shear test was carried out for determination of shear strength of soldered joints. Measurements were realised on two ceramic $\left(\mathrm{Al}_{2} \mathrm{O}_{3}\right.$ and $\left.\mathrm{SiC}\right)$ and five metallic $(\mathrm{Al}, \mathrm{Ni}, \mathrm{Ti}$, $\mathrm{Cr}-\mathrm{Ni}$ steel, and $\mathrm{Cu}$ ) materials with Sn2La solder. The shear strength was measured on versatile tearing equipment type LabTest 5.250SP1-VM. An especially developed shearing jig was used for changing the direction of tensile loading forces acting on the specimen. This shear jig assures a uniform loading of the specimen in shear in the plane boundary between the solder and substrate (Figure 4). The dwell time at a soldering temperature during specimen fabrication was $30 \mathrm{~s}$ and the ultrasound period was $5 \mathrm{~s}$.

\section{Experimental Results}

3.1. Analysis of Sn2La Solder. Figure 5 shows the macrostructure of Sn2La solder on ingot cross section. Clearly visible La phases, uniformly distributed in tin matrix, may be seen. The uniform distribution of La phases in tin matrix can be seen also on solder microstructure shown in Figure 6. A detailed view of La phase may be seen in Figure 7. No La was observed in the matrix of solder studied. Solder matrix is formed of pure tin. This was proved by EDS analysis.

The results of XRD analysis in Figure 8 prove that the solder matrix is formed of pure tin, where lanthanum phases, $\mathrm{LaSn}_{3}$, also occur. Similarly, the presence of $\mathrm{LaSn}_{3}$ phase was proved by EDS analysis. The point analysis of $\mathrm{LaSn}_{3}$ phase in the solder is documented in Figure 9.

The authors' opinion in [17] and the binary La-Sn system also proves the presence of $\mathrm{LaSn}_{3}$ phase at lanthanum content 2 wt.\% La (Figure 10).

DSC analysis was performed to identify the melting point of Sn2La solder. Measurements were taken in three subsequent cycles called RUN1, RUN2, and RUN3. DSC record of Sn2La solder is shown in Figure 11. From the curve course, it is obvious that the start of solder melting is at temperature $232.1^{\circ} \mathrm{C}$, which approximately corresponds to the melting point of pure tin. The temperature peak is at $237.2^{\circ} \mathrm{C}$. According to the binary La-Sn diagram in Figure 10, the eutectic phase transformation at temperature $235 \pm 2^{\circ} \mathrm{C}$ is concerned. The solder is already fully molten at temperature $243.6^{\circ} \mathrm{C}$. The presence of $2 \mathrm{wt} . \% \mathrm{La}$ in the tin solder matrix resulted in a shift of melting temperature of Sn2La by approximately $5^{\circ} \mathrm{C}$, compared to the melting point of pure tin.

3.2. Analysis of Boundary of $\mathrm{Al}_{2} \mathrm{O}_{3} / \mathrm{Sn} 2 \mathrm{La}$ Soldered Joint. Solder microstructure obtained by SEM after soldering with power ultrasound on $\mathrm{Al}_{2} \mathrm{O}_{3} / \mathrm{Sn} 2 \mathrm{La}$ solder boundary is shown in Figure 12. Since the soldering was performed in air, the La containing phases oxidised. Lanthanum is concentrated in great, considerably oxidised phases in size from 5 to $60 \mu \mathrm{m}$, as is clearly visible in Figure 12. Some phases are with sharp edges (Figure 14). However, this phenomenon was not observed in case of soldering $\mathrm{Cu} / \mathrm{Sn} 2 \mathrm{La}$ solder $/ \mathrm{Cu}$ 


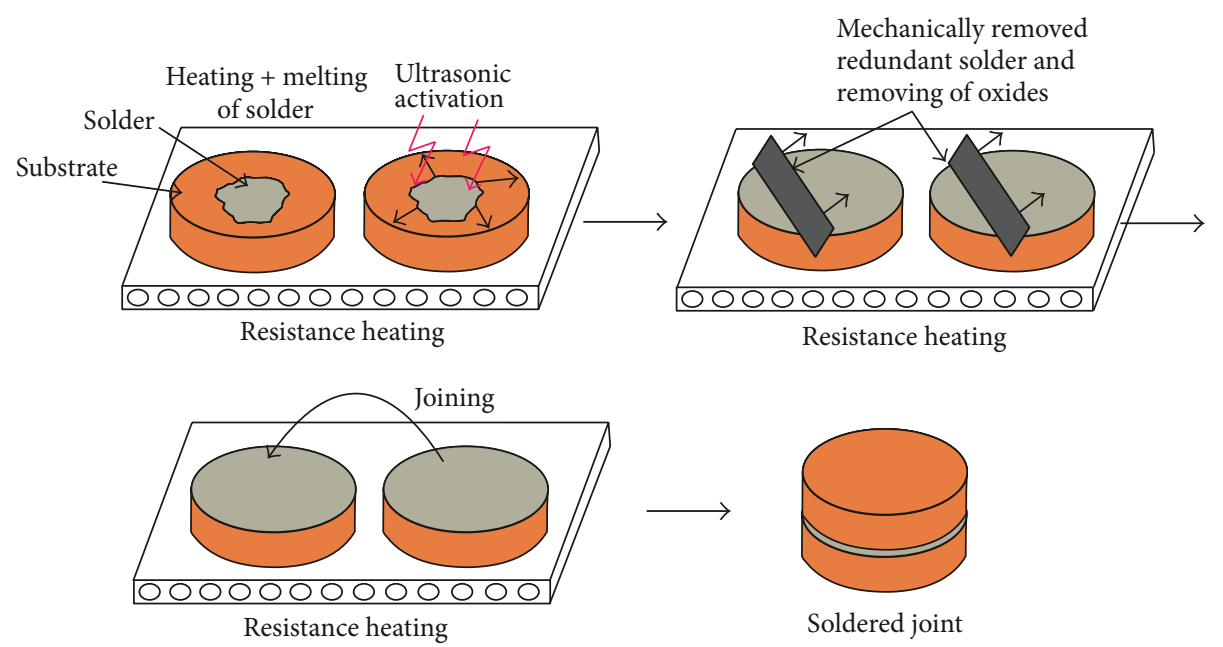

Figure 3: Procedure of joint fabrication by ultrasonic soldering.
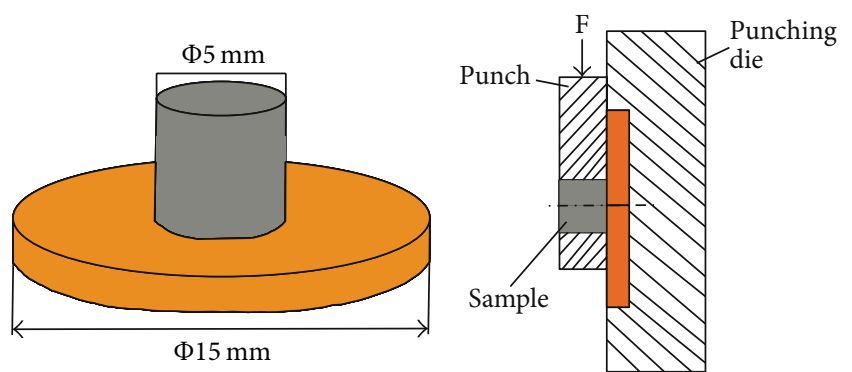

FIGURE 4: Test specimen for shear test and scheme of specimen in a jig during shear strength testing.

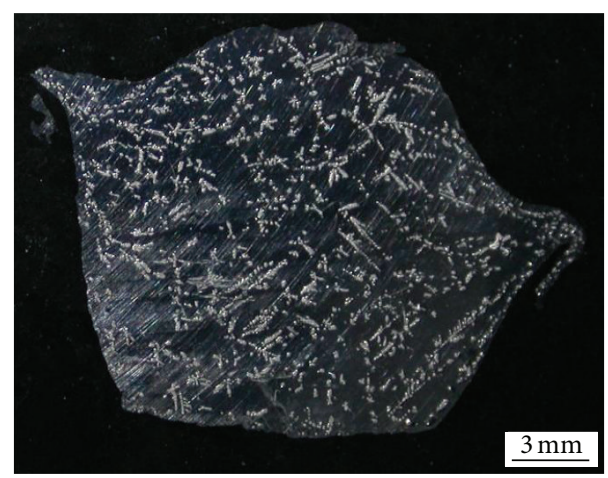

FIGURE 5: Macrostructure of Sn2La solder ingot.

joint. In this case, La remains uniformly distributed in the solder matrix structure. Great oxidised La phases scarcely occur. These facts suggest that formation of great oxidised $\mathrm{La}$ phases is related to $\mathrm{La}$ interaction with the surface of $\mathrm{Al}_{2} \mathrm{O}_{3}$. Comparison of microstructures of soldered $\mathrm{Al}_{2} \mathrm{O}_{3} / \mathrm{SiC}$ and $\mathrm{Cu} / \mathrm{Cu}$ joints from optical microscopy is documented in Figure 13.
During the course of study with bounced electrons (BSE), lanthanum should glow, but due to the fact that it is enriched by oxygen, the La containing particle is dark (Figure 14).

Oxidised lanthanum particles from Figure 14 contain 9.56 wt. $\% \mathrm{O}_{2}, 18.20$ wt.\% Sn, and 72.24 wt.\% La. Point analysis of sharp-edged lanthanum particle is documented in Figure 15.

Solder matrix in $\mathrm{Al}_{2} \mathrm{O}_{3} / \mathrm{Sn} 2 \mathrm{La}$ soldered joint is composed of almost pure tin (the accuracy of EDS analysis should be taken into account). The point analysis of matrix is documented in Figure 16. The matrix is composed of finegrained tin structure.

As was shown, considerable amount of lanthanum is oxidised during soldering in the air. The lanthanum particles are distributed to the boundary with ceramic material owing to the effect of ultrasonic activation (Figures 17 and 18). The concentration line of La in Figure 17 proves increased La concentration on the boundary with $\mathrm{Al}_{2} \mathrm{O}_{3}$ ceramics. In Figure 18, one can see a uniform continuous layer of lanthanum particles on the boundary with ceramic material, which ensures the joint formation. This layer is around $1.5 \mu \mathrm{m}$ thick. In spite of this layer, the solder is more or less adhered to the ceramic substrate. The bond with ceramic material is of adhesive character. No formation of intermetallic phases was observed, which also causes lower shear strength of joints with ceramic materials.

3.3. Boundary Analysis of Cu/Sn2La/Cu Soldered Joint. When soldering copper substrate with Sn2La solder, it was found that the solder matrix is also formed of pure tin, similarly as in cases of joints with $\mathrm{Al}_{2} \mathrm{O}_{3}$ ceramics. Redistribution of greater constituents containing lanthanum (Figure 19) was caused by ultrasound activation. The solder structure in $\mathrm{Cu} / \mathrm{Sn} 2 \mathrm{La} / \mathrm{Cu}$ joints differs from the $\mathrm{Al}_{2} \mathrm{O}_{3} / \mathrm{Sn} 2 \mathrm{La} / \mathrm{Al}_{2} \mathrm{O}_{3}$ joints. Lanthanum in the case of the $\mathrm{Cu} / \mathrm{Sn} 2 \mathrm{La} / \mathrm{Cu}$ joint was uniformly distributed on the grain boundaries of tin in the form of very fine $\mathrm{LaSn}_{3}$ phases (Figures 19 and 20). The particles 

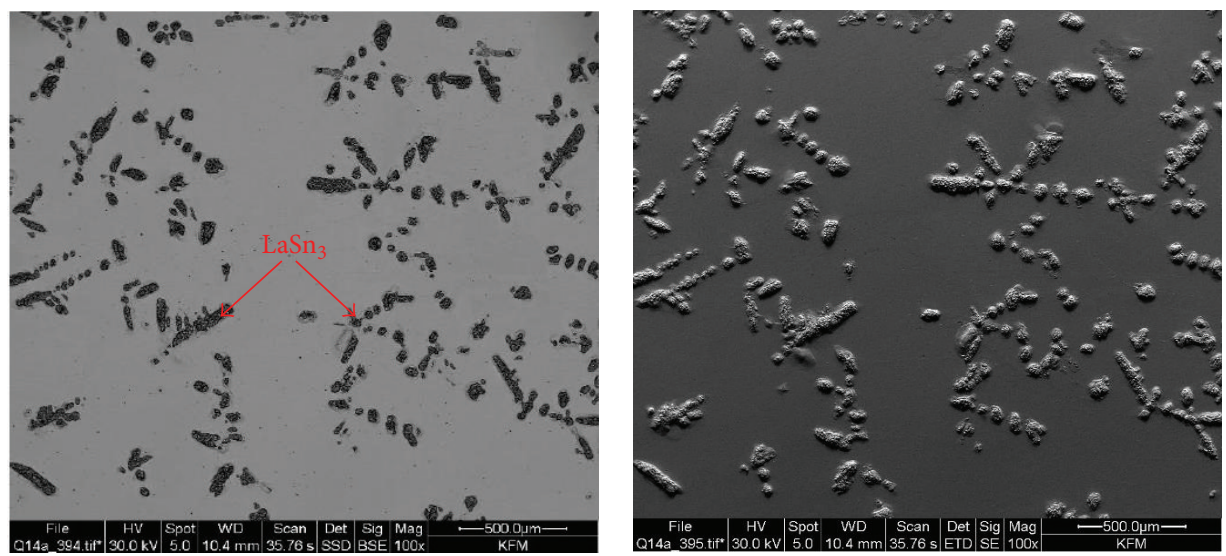

Figure 6: Microstructure of Sn2La solder.

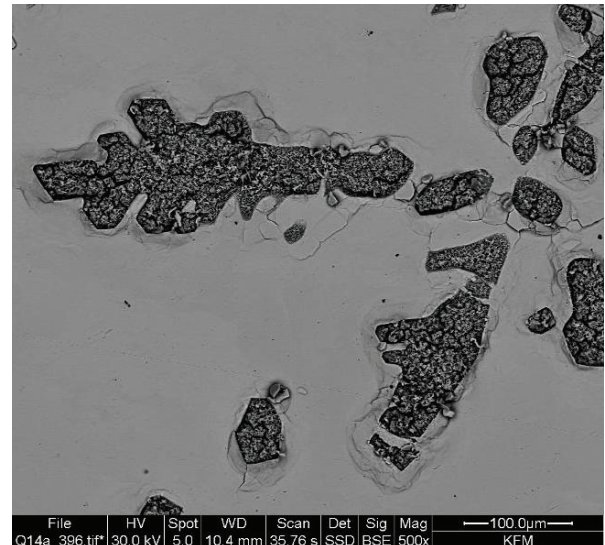

FIgURE 7: Detail of La phase in Sn2La solder matrix.

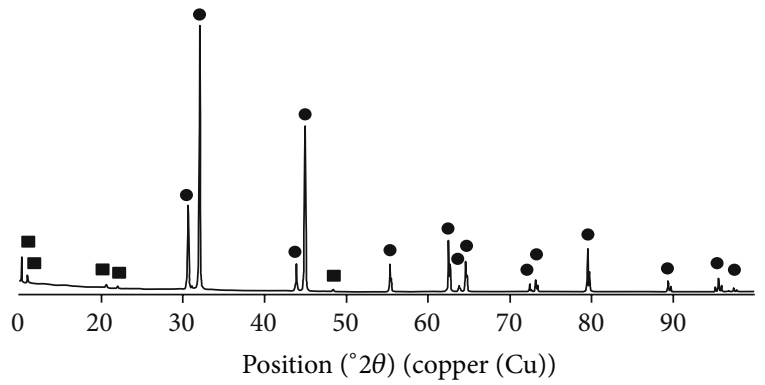

- $\beta \mathrm{Sn}$

- $\mathrm{LaSn}_{3}$

FIGURE 8: Diffraction records of Sn2La solder.

of this phase are very fine with their size ranging from 0.25 to $0.35 \mu \mathrm{m}$. It is surprising that due to La presence in solder matrix the copper is not dissolved in tin matrix. Normally, the $\mathrm{Cu}$ concentration in $\mathrm{Sn}$ should be almost 1 wt.\%.

The intermetallic $\mathrm{Cu}_{6} \mathrm{Sn}_{5}$ and $\mathrm{Cu}_{3} \mathrm{Sn}$ phases were formed on the boundary of copper substrate and tin solder during ultrasonic soldering. Fine arches of those intermetallic phases
kV: 20.0 Tilt: 0.0 Take-off: 34.9 Det type: SDD Apollo XP Res: 134 Amp. T: 25.60 FS: 2216 Lsec: 30

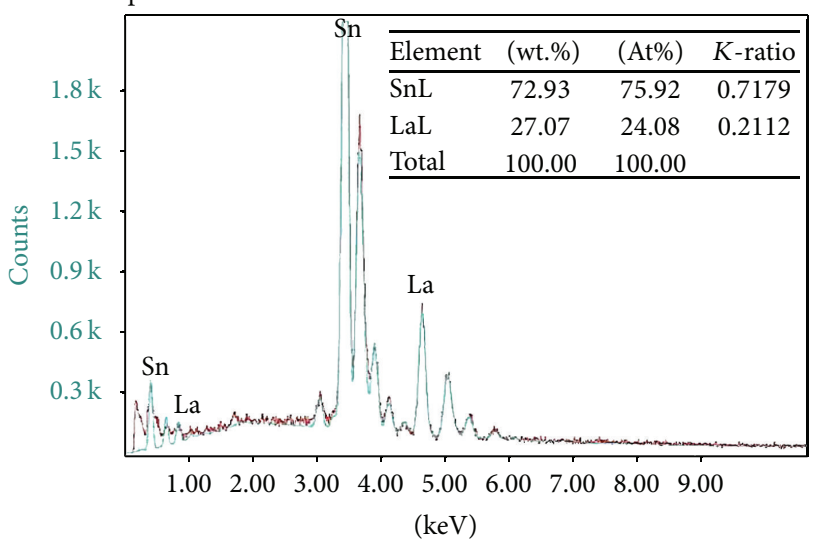

FIgURE 9: Point analysis of $\mathrm{LaSn}_{3}$ composition in $\mathrm{Sn} 2 \mathrm{La}$ solder.

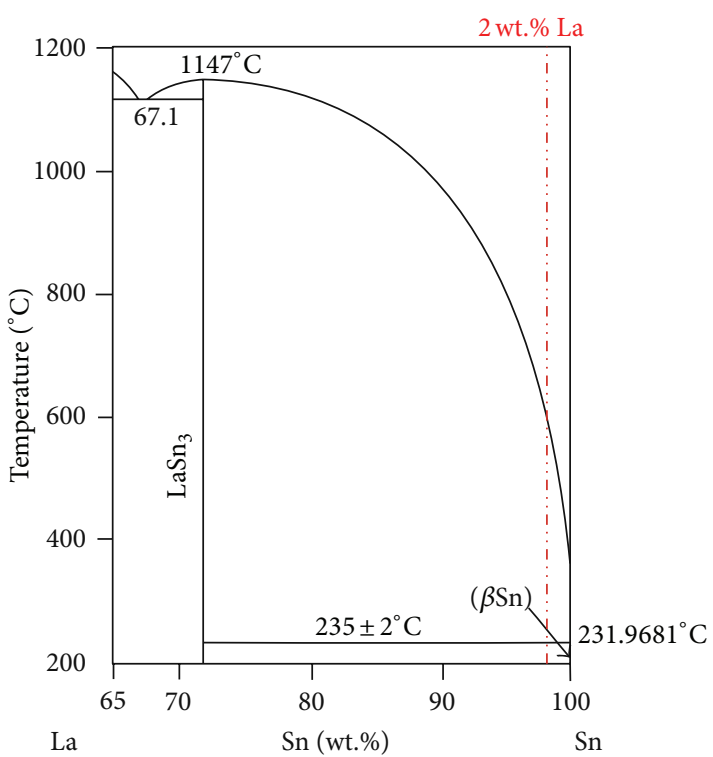

Figure 10: Binary La-Sn diagram [18]. 


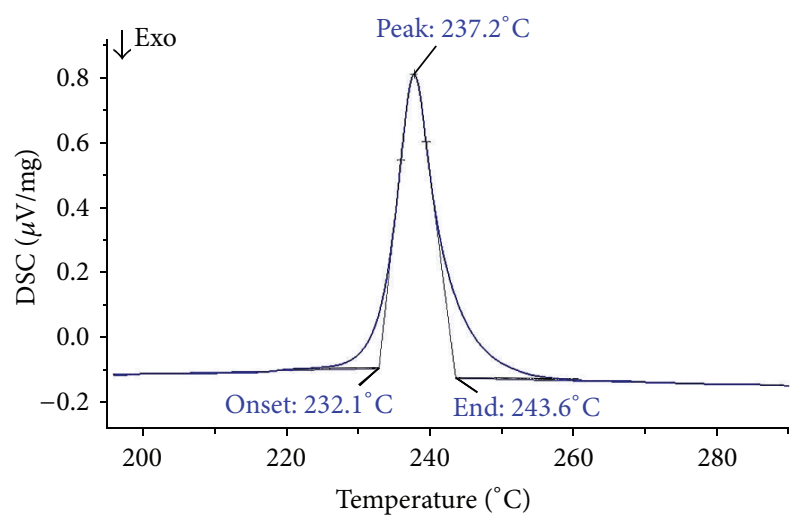

FIGURE 11: DSC analysis of Sn2La solder.

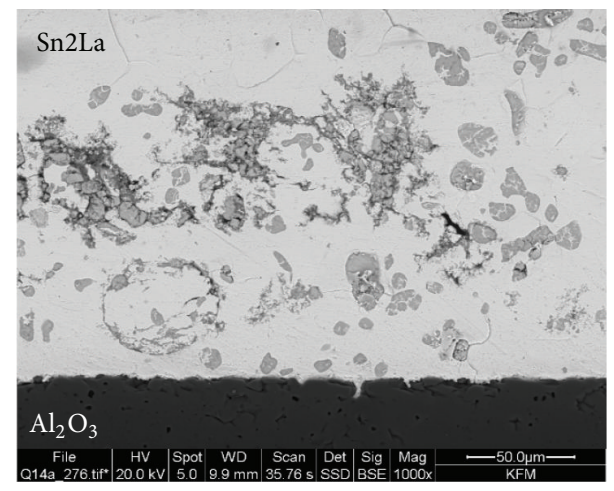

FIGURE 12: Boundary microstructure of $\mathrm{Al}_{2} \mathrm{O}_{3} / \mathrm{Sn} 2 \mathrm{La}$ joint after soldering with active ultrasound.

with maximum thickness of $4 \mu \mathrm{m}$ are seen in Figure 20. The $\mathrm{Cu}_{3} \mathrm{Sn}$ phase is very thin and therefore less visible. It was identified by EDS analysis. From these results, we may conclude that $\mathrm{La}$ in the solder prevents dissolution of $\mathrm{Cu}$ in tin solder and hinders the growth of intermetallic $\mathrm{Cu}_{6} \mathrm{Sn}_{5}$ and $\mathrm{Cu}_{3} \mathrm{Sn}$ phases, which is advantageous from the viewpoint of the life of joints subjected to thermal cycling.

Contrary to $\mathrm{Al}_{2} \mathrm{O}_{3} / \mathrm{Sn} 2 \mathrm{La}$ joint, also greater constituent of oxidised lanthanum phases seldom occurs in cases of $\mathrm{Cu} / \mathrm{Sn} 2 \mathrm{La}$ joints in solder matrix. The incidental oxidised La phase may be observed in Figures 20 and 21. The concentration profiles of $\mathrm{La}, \mathrm{Cu}, \mathrm{Sn}$, and $\mathrm{O}$ elements in Figure 21 show that the greatest oxygen amount, thus oxides, occurs in the lanthanum particle. In Figures 19, 20, and 21, purely visible uniformly distributed fine particles of $\mathrm{LaSn}_{3}$ phase are seen.

Beside the formation of transient metallic $\mathrm{Cu}_{6} \mathrm{Sn}_{5}$ and $\mathrm{Cu}_{3} \mathrm{Sn}$ phases, we also observe planar distribution of $\mathrm{La}$, $\mathrm{O}$, and Sn elements in sharp-edged oxidised particle with high lanthanum contents on the planar analysis of soldered $\mathrm{Cu} /$ solder Sn2La joint in Figure 22.

3.4. The Results of Shear Strength in Soldered Joints. Research in this study was primarily oriented to soldering ceramic $\mathrm{Al}_{2} \mathrm{O}_{3}$ substrate and copper substrate. These experiments determining shear strength of soldered joints were also extended to other metallic materials ( $\mathrm{Al}, \mathrm{Ni}, \mathrm{Ti}$, and $\mathrm{CrNi}$ steel) and $\mathrm{SiC}$ ceramics in order to show the wider applicability of Sn2La solder.

Measurements were performed on 4 specimens of each material. The resulting average shear strengths are documented in Figure 23. The lowest shear strength was observed on $\mathrm{Al}_{2} \mathrm{O}_{3}$ ceramics $(7.5 \mathrm{MPa})$. Somewhat higher strength (13.5 MPa) was observed on $\mathrm{SiC}$ ceramics and the highest was achieved on $\mathrm{Al}$ and $\mathrm{Ni}$. The shear strength on copper substrate was 26.0 MPa.

The Sn2La solder showed relatively wide variables in shear strength on metallic and ceramic materials. We found the shear strength of joints in metallic materials to be nearly 3 times higher than that in case of ceramic materials. For more correct identification, the fractured surfaces of $\mathrm{Cu} / \mathrm{Sn} 2 \mathrm{La}$ and $\mathrm{Al}_{2} \mathrm{O}_{3} / \mathrm{Sn} 2 \mathrm{La}$ joints (Figures 24 and 25) were also analysed.

The $\mathrm{Cu} / \mathrm{Sn} 2 \mathrm{La}$ joint showed formation of a typical ductile failure by shear mechanism (Figure 24). The fracture morphology clearly shows the motion of the shearing tool. Figure 25 shows the documented fractured surfaces of $\mathrm{Al}_{2} \mathrm{O}_{3} / \mathrm{Sn} 2 \mathrm{La}$ joint. Fracture surface is without visible tracks of shear tool, so the failure occurred by tearing without a shearing mechanism. 100\% Sn2La solder covering remained on the $\mathrm{Cu}$ substrate after the test. On the opposite, Sn2La solder was torn from the ceramic substrate. The $\mathrm{Al}_{2} \mathrm{O}_{3}$ substrate remained only partially covered by Sn2La.

\section{Discussion}

Lanthanum present in form of $\mathrm{LaSn}_{3}$ in the volume of Sn2La solder is inefficient at soldering temperature $290^{\circ} \mathrm{C}$ and therefore it does not wet the ceramic material. Powerful ultrasound is thus necessary for its activation. At direct ultrasound activation through the layer of molten solder (Figure 2), the solder is extremely vibrated by titanium sonotrode. This allows significant diffusion of active La element from the solder matrix to boundary with ceramic and/or metallic material. This depends on mechanism of joint formation. In the zone of ultrasound impact, the temperature may be locally increased even up to $1000^{\circ} \mathrm{C}$ and more [33]. This enhances the physicochemical processes at joint formation.

The experiments have also shown that pure tin without addition of active element ( $\mathrm{La}$ ) does not wet $\mathrm{Al}_{2} \mathrm{O}_{3}$ material. The solder composed of pure tin is after melting first shrunk into globular form. Only fine particles of tin and tin oxides are formed by long-time acting of ultrasound, which are then sputtered over the surface of ceramic material without bond formation.

The results of direct soldering of ceramic and metallic materials have proven that $\mathrm{Sn}$ solder containing La ensures their wettability at application of ultrasonic activation, meaning that Sn2La solder is suitable for practical applications.

We suppose from the results of analysis performed in transition zone of soldered joints that the joint with a metallic material is of metallurgical-diffusion character. However, the joint with ceramic material, namely, $\mathrm{Al}_{2} \mathrm{O}_{3}$, is of adhesive character, when soldered with solder containing La. 

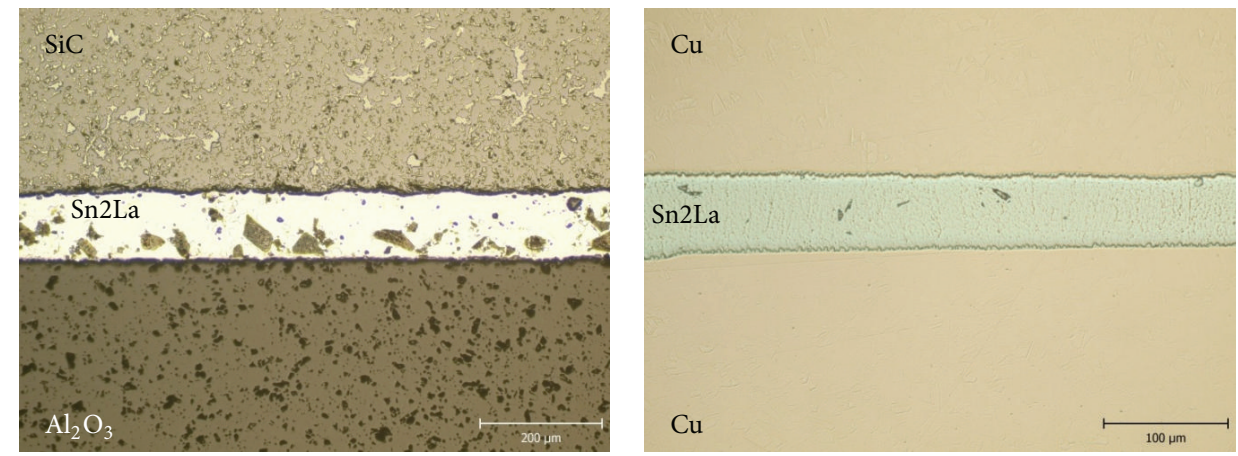

FIGURE 13: Comparison of microstructure of Sn2La solder after UT soldering at the same parameters and conditions of soldering.

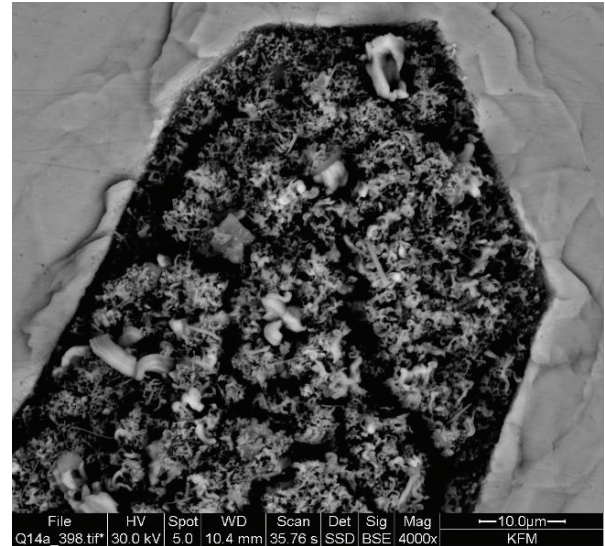

FIGURE 14: Sharp-edged oxidised lanthanum phase in $\mathrm{Al}_{2} \mathrm{O}_{3} / \mathrm{Sn} 2 \mathrm{La} /$ $\mathrm{Al}_{2} \mathrm{O}_{3}$ joint.

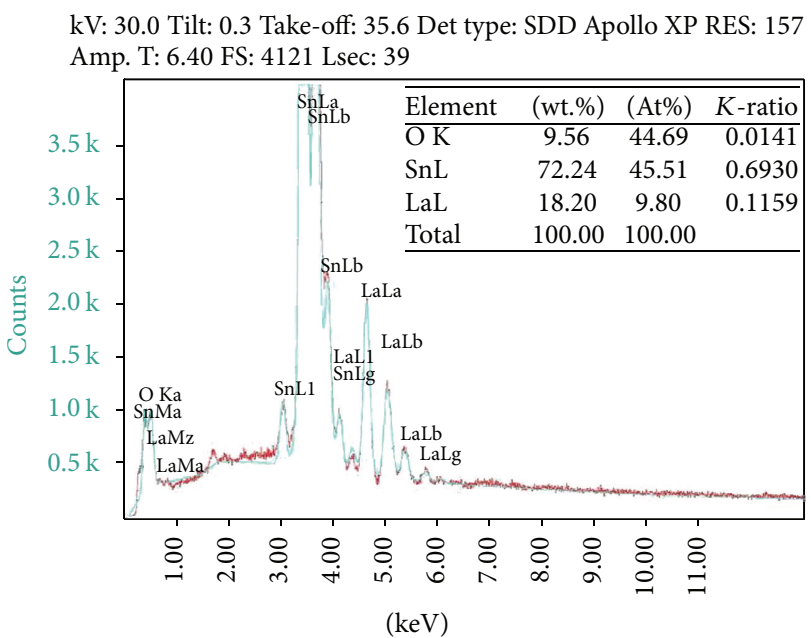

FIGURE 15: Point analysis of sharp-edged lanthanum particle.

A new transition layer with thickness around $1.5 \mu \mathrm{m}$ was observed on the boundary with the ceramic material. For example, in study $[10,11]$, a transition layer 2 to $6 \mathrm{~nm}$ was formed at application of $\mathrm{Zn}-\mathrm{Al}(\mathrm{Zn}-\mathrm{Al}-\mathrm{Mg}, \mathrm{Sn}-\mathrm{Zn}-\mathrm{Al})$ based solders. At application of $\mathrm{Sn}-\mathrm{Ag}$-Ti based solders, described in

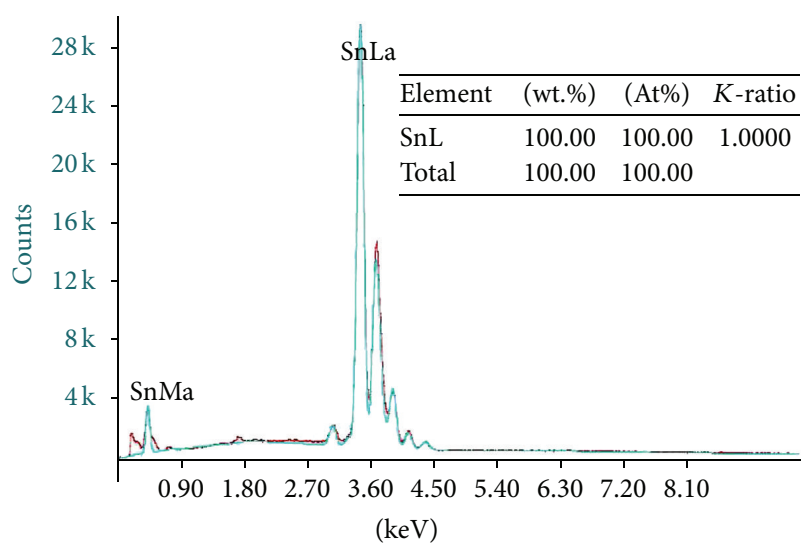

FIgure 16: Point analysis of solder matrix in $\mathrm{Al}_{2} \mathrm{O}_{3} / \mathrm{Sn} 2 \mathrm{La}$ solder joint.

work [12], the transition layer in thickness from 4 to $7 \mu \mathrm{m}$ was formed. The studies [12-14] proved that this transition layer ensures the joint formation at direct soldering of ceramic materials.

In case of application of $\mathrm{Sn} 2 \mathrm{La}$ solder for soldering $\mathrm{Al}_{2} \mathrm{O}_{3}$ ceramics, we observed no formation of soldered joint of diffusion character with creation of new products. The shear strength of $\mathrm{Al}_{2} \mathrm{O}_{3} / \mathrm{Sn} 2 \mathrm{La}$ joint was $7.5 \mathrm{MPa}$, shear strength of $\mathrm{SiC} / \mathrm{Sn} 2 \mathrm{La}$ joint was $13.5 \mathrm{MPa}$, and shear strength of $\mathrm{Cu} / \mathrm{Sn} 2 \mathrm{La}$ joint was 26.0 MPa.

For comparison of results of shear strength, we also give the results from similar studies, while it must be taken into account that different researchers are using different test methods, shape of specimens, and loading rate during testing. They are also using different compositions of soldering alloys and different soldering parameters. For example, at application of solders type $\mathrm{Zn}-\mathrm{Al}(\mathrm{Zn} 14 \mathrm{Al})$ in work [11] on $\mathrm{Al}_{2} \mathrm{O}_{3} / \mathrm{Zn} 14 \mathrm{Al} / \mathrm{Cu}$ joint, the achieved shear strength was $80 \mathrm{MPa}$ at ultrasound power of $200 \mathrm{~W}$. In study [12], the joint of ceramic SiC substrates soldered with Zn8.5AllMg solder achieved shear strength of $148.1 \mathrm{MPa}$ at ultrasound acting for $8 \mathrm{~s}$.

In study [13], sapphire was soldered with ultrasound assistance at application of Sn10Zn2Al solder. The shear strength 

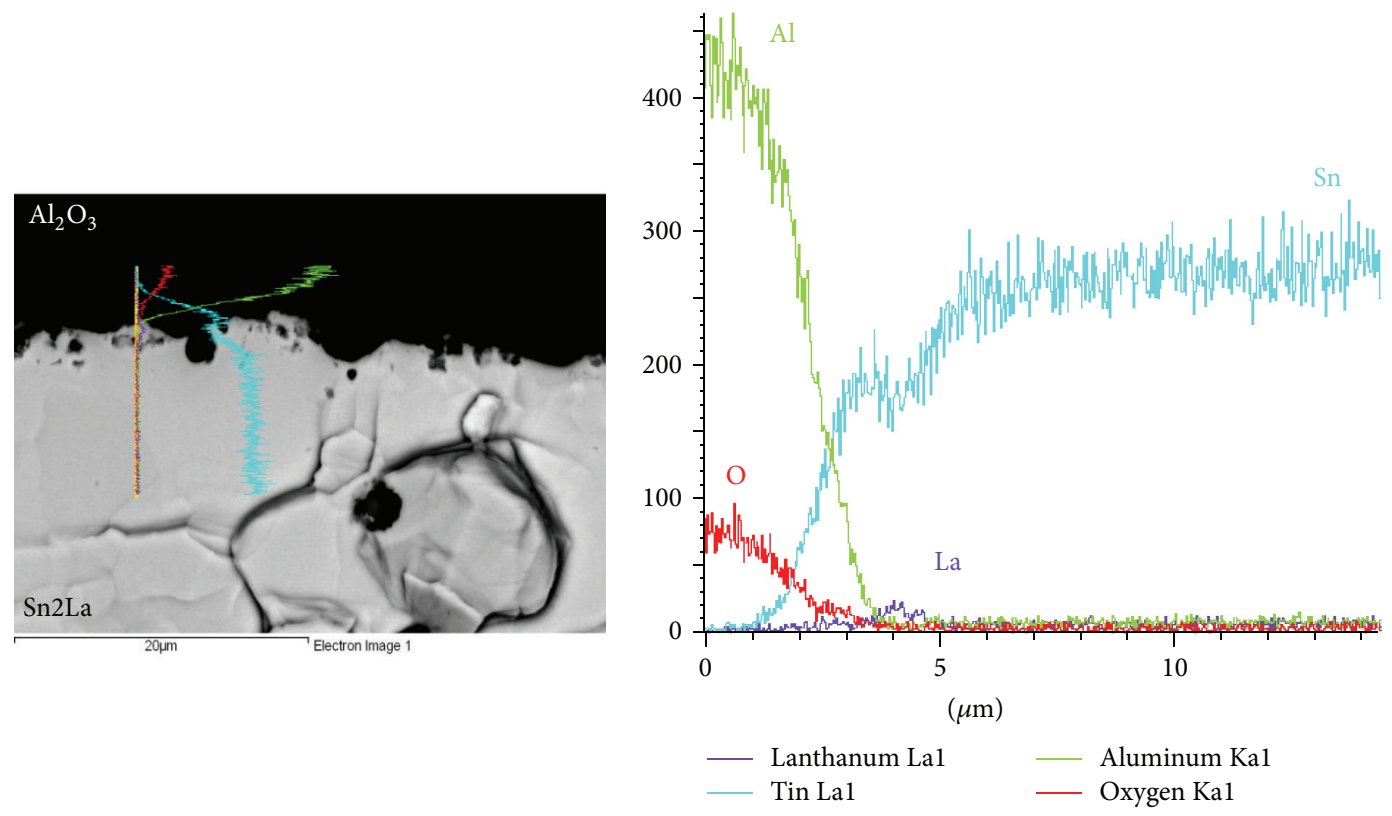

FIGURE 17: Concentration profiles of $\mathrm{Al}, \mathrm{Sn}, \mathrm{La}$, and $\mathrm{O}_{2}$ on $\mathrm{Al}_{2} \mathrm{O}_{3} / \mathrm{Sn} 2 \mathrm{La}$ solder boundary.

TABLE 2: Comparison of achieved shear strength of $\mathrm{Al}_{2} \mathrm{O}_{3}$ /solder joints.

\begin{tabular}{lcc}
\hline Substrate & Solder alloy & Shear strength $[\mathrm{MPa}]$ \\
\hline \multirow{3}{*}{$\mathrm{Al}_{2} \mathrm{O}_{3}$} & Sn2La & 7.5 \\
& Zn14Al [11] & 80 \\
& Sn10Zn2Al [13] & $43-48$ \\
& Sn3,5Ag4Ti(Ce,Ga) [14] & 13.5 \\
& Sn3,5Ag4Ti(Ce,Ga) [16] & 24 \\
\hline
\end{tabular}

of joints in that case attained 43 to $48 \mathrm{MPa}$. Several studies dealt with type $\mathrm{Sn}$-Ag-Ti solders. The new metallic, ceramic, and nonmetallic materials were also tested. For example, in study [16], the $\mathrm{Al}_{2} \mathrm{O}_{3} / \mathrm{Sn}-\mathrm{Ag}-\mathrm{Ti} / \mathrm{Al}_{2} \mathrm{O}_{3}$ joint exerted the shear strength of $24 \mathrm{MPa}$. In [15], the following strength values were achieved: $\mathrm{Cu} / \mathrm{Cu}(14.3 \mathrm{MPa})$, ITO/ITO (6.8 MPa), and ITO/Cu (3.4) MPa. Similar examples are also mentioned in study [14], where shear strength of alumina/alumina joint was 13.5 MPa, copper/copper 14.3 MPa, and alumina/copper $10.2 \mathrm{MPa}$.

A brief overview of shear strength of $\mathrm{Al}_{2} \mathrm{O}_{3}$ /solder joints achieved by mentioned authors is documented in Table 2.

\section{Conclusions}

The aim of this work was to study direct bonding of $\mathrm{Al}_{2} \mathrm{O}_{3}$ ceramics with copper substrate. We studied whether Snbased solder alloyed with $\mathrm{La}$ can wet the $\mathrm{Al}_{2} \mathrm{O}_{3}$ ceramics and other ceramic materials and thus form strong joints. For this reason, analyses were performed to reveal the mechanism of joint formation and also measure the shear strength of fabricated joints. The following results were achieved:

(i) DSC analysis has shown that Sn2La solder has a melting point of $273.2^{\circ} \mathrm{C}$, which is approximately $5^{\circ} \mathrm{C}$ more than the melting temperature of pure tin.

(ii) The matrix of $\mathrm{Sn} 2 \mathrm{La}$ solder after soldering $\mathrm{Al}_{2} \mathrm{O}_{3}$ ceramics as well as the copper substrate is formed of almost pure tin, where fine particles of $\mathrm{SnLa}_{3}$ phase are segregated along the grain boundaries.

(iii) The bond of Sn2La solder with $\mathrm{Cu}$ substrate at ultrasound application occurs due to formation of fine bridges of $\mathrm{Cu}_{6} \mathrm{Sn}_{5}$ and $\mathrm{Cu}_{3} \mathrm{Sn}$ phases on the $\mathrm{Cu}$ substrate/Sn2La solder boundary. Thickness of these transition phases is extremely low ( $\max .4 \mu \mathrm{m})$. Comparison has shown that the growth of layer of transition intermetallic phases is prevented by fine La phases precipitated along the grain boundaries.

(iv) Bond formation between $\mathrm{Sn} 2 \mathrm{La}$ solder and $\mathrm{Al}_{2} \mathrm{O}_{3}$ substrate occurs at activation of lanthanum phases by ultrasound. Lanthanum contained in the solder volume is oxidised on the air during soldering. The lanthanum particles are distributed to boundary of ceramic material owing to ultrasonic activation. Lanthanum particles are then bound with surface oxides on ceramic material. A thin uniform layer containing La is formed on the boundary with ceramics.

(v) The lowest shear strength was observed on $\mathrm{Al}_{2} \mathrm{O}_{3}$ ceramics $(7.5 \mathrm{MPa})$. Somewhat higher strength was achieved on $\mathrm{SiC}$ ceramics $(13.5 \mathrm{MPa})$. The highest strength within the metallic materials was achieved 

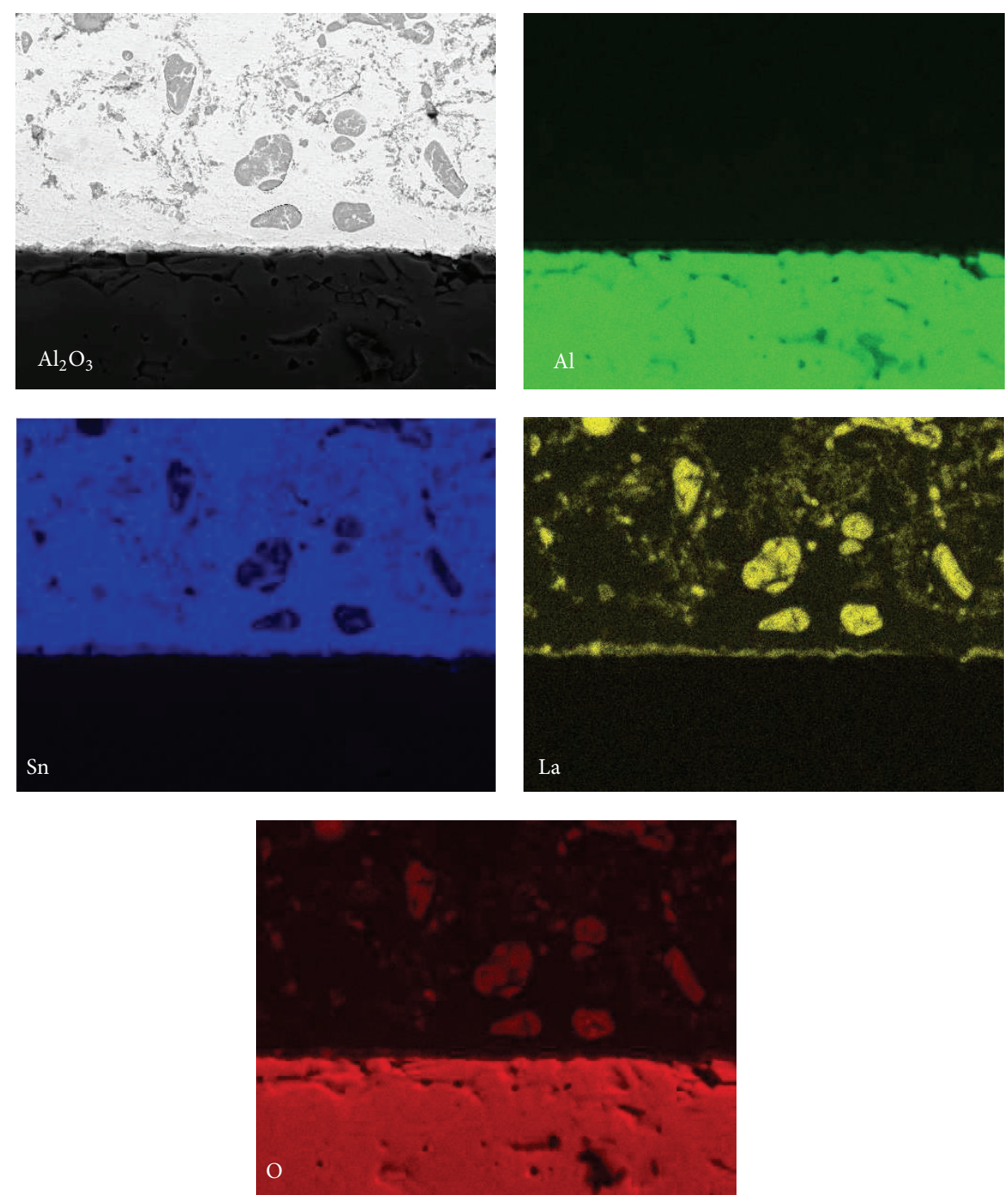

FIGURE 18: Planar EDX analysis of soldered $\mathrm{Sn} 2 \mathrm{La} / \mathrm{Al}_{2} \mathrm{O}_{3}$ boundary.

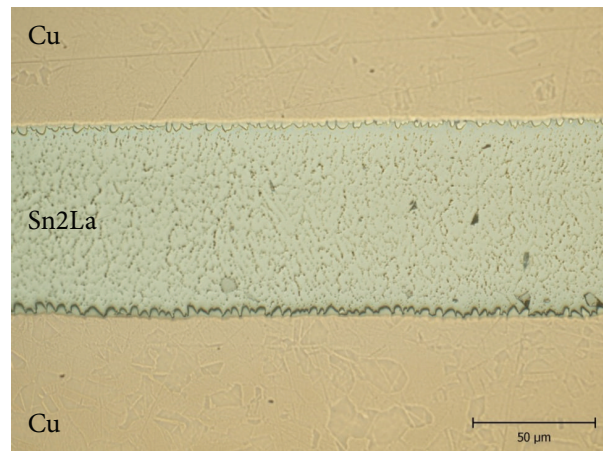

Figure 19: Microstructure of $\mathrm{Cu} / \mathrm{Sn} 2 \mathrm{La} / \mathrm{Cu}$ joint from the light optical analysis. 


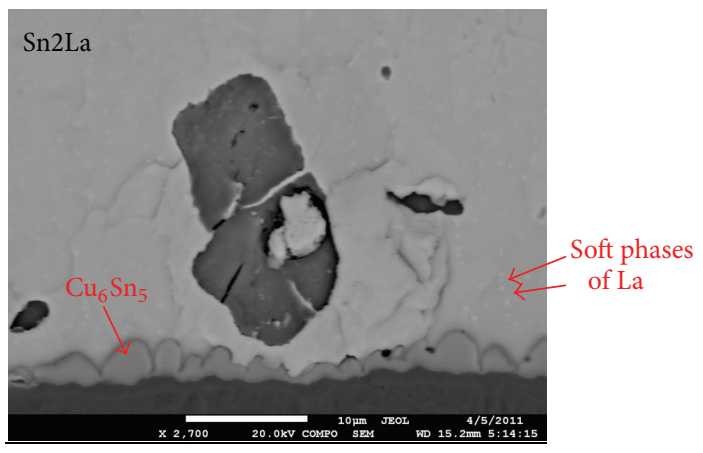

FIGURE 20: Fine arches of intermetallic $\mathrm{Cu}_{6} \mathrm{Sn}_{5}$ phases and incidental greater oxidised La phase in tin matrix of Cu/Sn2La joint.
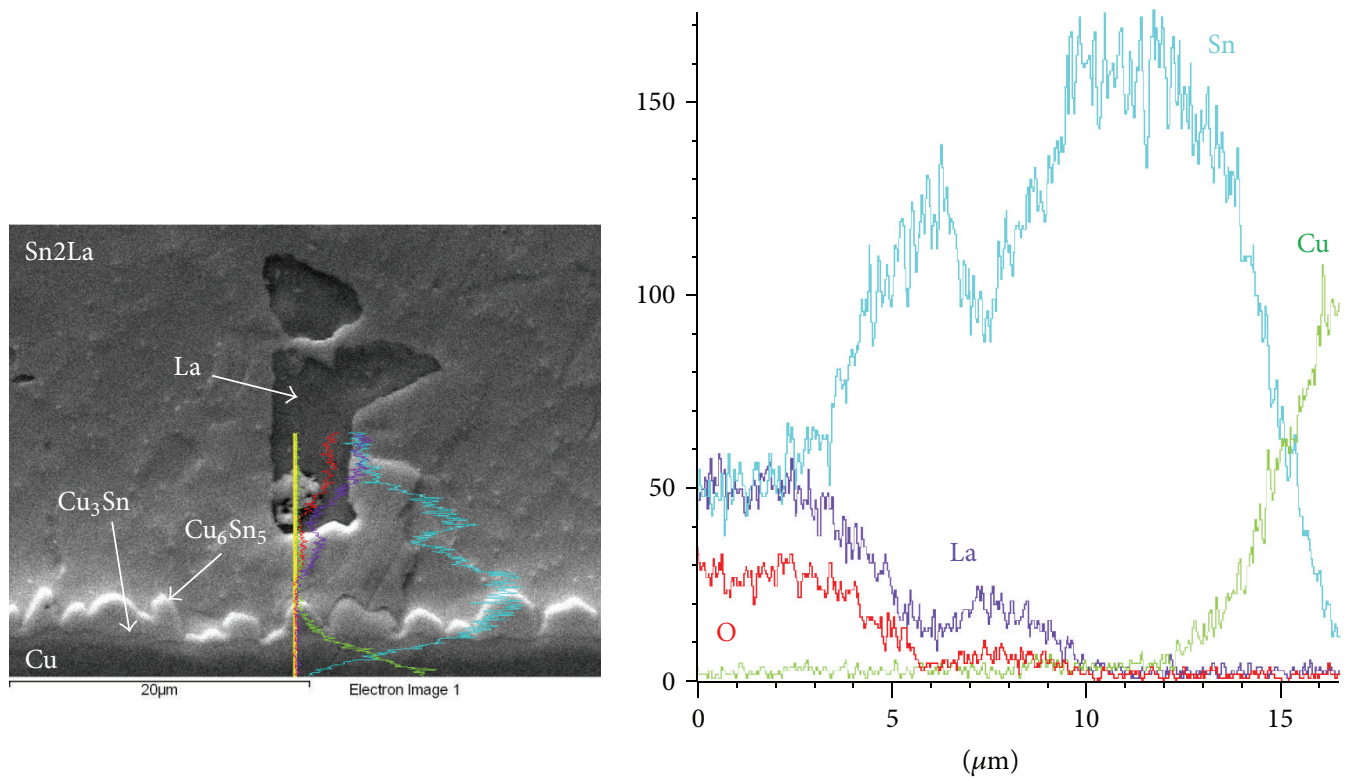

FIgURE 21: Microstructure of Cu/Sn2La boundary (SEM) with concentration profiles of $\mathrm{La}, \mathrm{Cu}, \mathrm{Sn}$, and O elements.
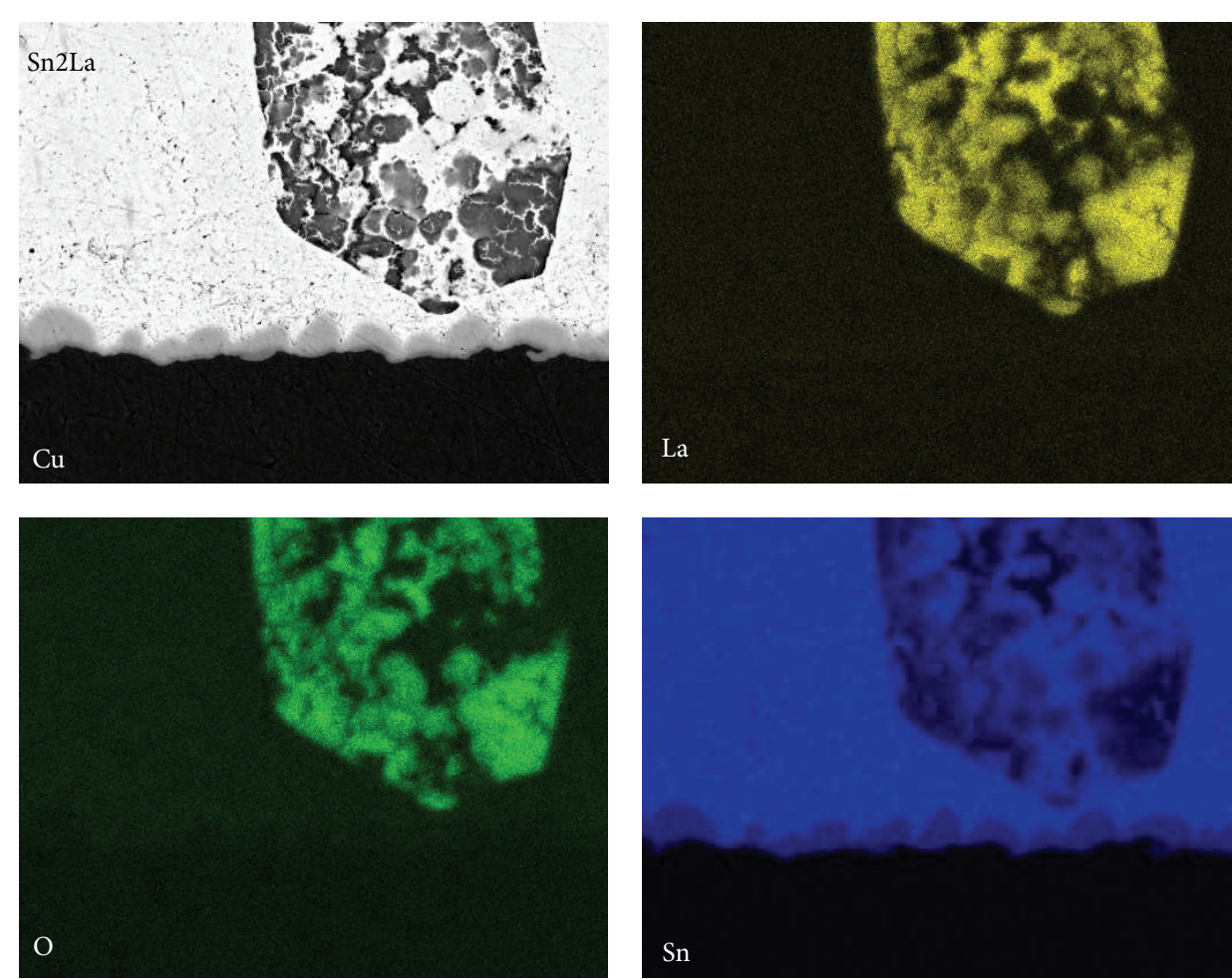

FIGURE 22: Planar analysis of $\mathrm{Cu} / \mathrm{Sn} 2 \mathrm{La}$ joint boundary with a sharp-edged lanthanum particle. 


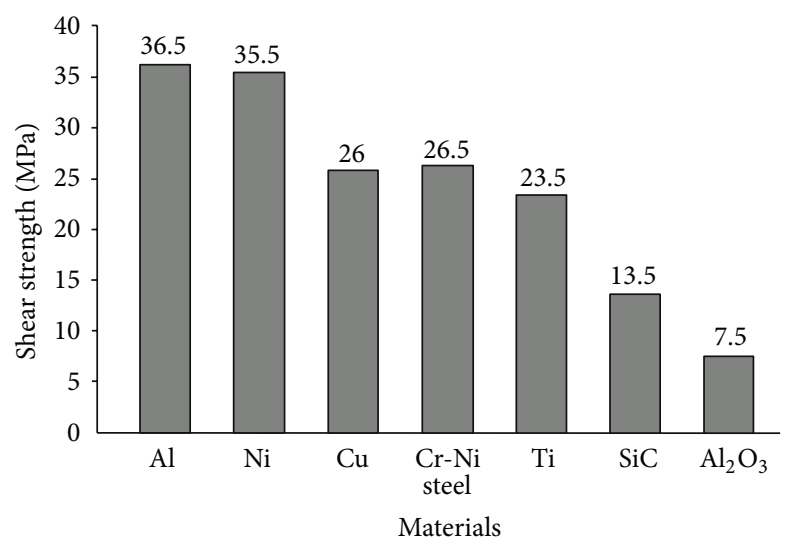

FIGURE 23: Measured results of shear strength of joints fabricated with Sn2La solder.
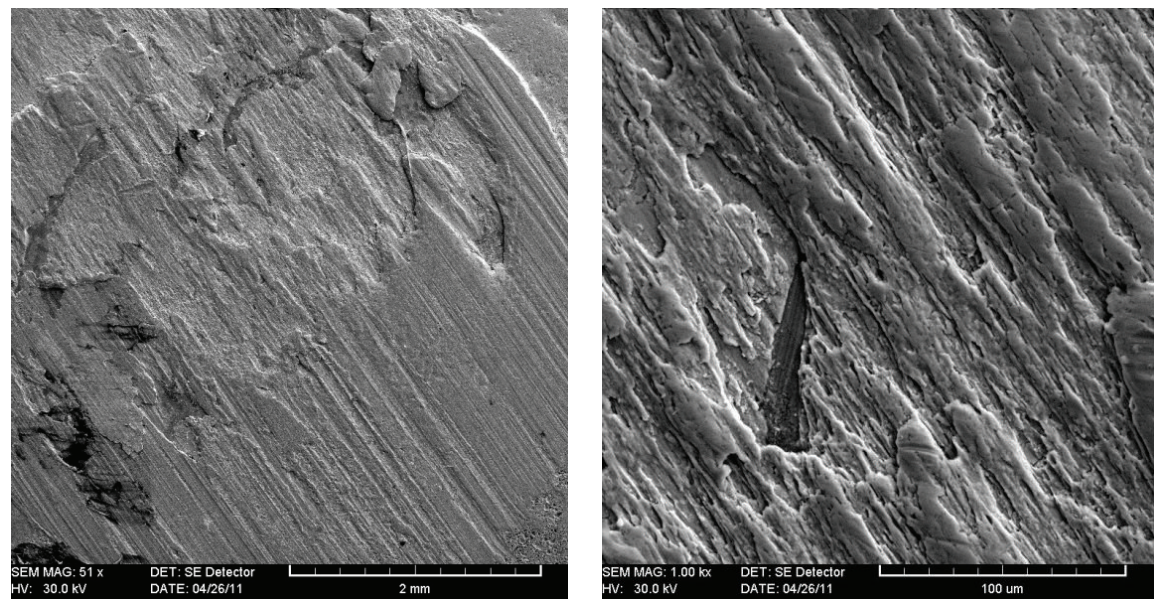

Figure 24: Fractured surface of Sn2La/Cu joint.
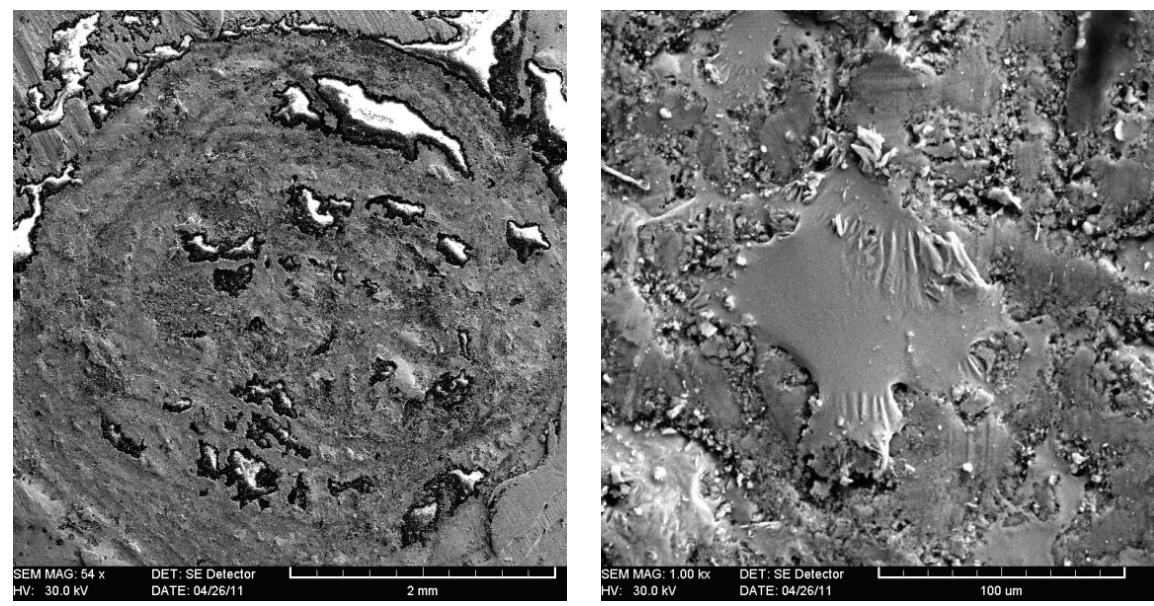

Figure 25: Fractured surface of $\mathrm{Sn} 2 \mathrm{La} / \mathrm{Al}_{2} \mathrm{O}_{3}$ joint.

on $\mathrm{Al}$ and $\mathrm{Ni}$ (around $35 \mathrm{MPa}$ ). The strength attained on copper substrate was $26.0 \mathrm{MPa}$.

(vi) From the results of analysis of transition zones in soldered joints, measurements of shear strength, and fractographic analysis of fractured surfaces, we suppose that the bond with metallic material is of metallurgical-diffusion character. The bond with ceramic material, namely, $\mathrm{Al}_{2} \mathrm{O}_{3}$, soldered with $\mathrm{La}$ containing solder is of an adhesive character. 


\section{Conflict of Interests}

The authors declare that there is no conflict of interests regarding the publication of this paper.

\section{Acknowledgments}

The contribution was prepared with the support of APVV0023-12, research of new soldering alloys for fluxless soldering with application of beam technologies and ultrasound, and VEGA 1/0455/14, research of modified solders for fluxless soldering of metallic and ceramic materials. The authors thank Ing. Marián Drienovský, Ph.D., for DSC analysis; Associate Professor Ing. Maroš Martinkovič, Ph.D., for shear strength measurements, Ing. Jiří Faltus, CSc., for EDS analysis, and Ing. Ivona Černičková, Ph.D., for EDX analysis.

\section{References}

[1] C. H. Liu, Y. J. Kim, D. W. Chun et al., "Universal solders for direct bonding and packaging of optical devices," Materials Letters, vol. 152, pp. 232-236, 2015.

[2] A. A. El-Daly, A. M. El-Taher, and S. Gouda, "Development of new multicomponent $\mathrm{Sn}$-Ag-Cu-Bi lead-free solders for lowcost commercial electronic assembly," Journal of Alloys and Compounds, vol. 627, pp. 268-275, 2015.

[3] E. H. Amalu, W. K. Lau, N. N. Ekere et al., "A study of SnAgCu solder paste transfer efficiency and effects of optimal reflow profile on solder deposits," Microelectronic Engineering, vol. 88, no. 7, pp. 1610-1617, 2011.

[4] J. Lemus-Ruiz, A. O. Guevara-Laureano, J. Zarate-Medina, A. Arellano-Lara, and L. Ceja-Cárdenas, "Interface behavior of $\mathrm{Al}_{2} \mathrm{O}_{3} / \mathrm{Ti}$ joints produced by liquid state bonding," Applied Radiation and Isotopes, vol. 98, pp. 1-6, 2015.

[5] W.-Y. Yu, S.-H. Liu, X.-Y. Liu, M.-P. Liu, and W.-G. Shi, "Interface reaction in ultrasonic vibration-assisted brazing of aluminum to graphite using $\mathrm{Sn}-\mathrm{Ag}$-Ti solder foil," Journal of Materials Processing Technology, vol. 221, pp. 285-290, 2015.

[6] T. Zaharinie, R. Moshwan, F. Yusof, M. Hamdi, and T. Ariga, "Vacuum brazing of sapphire with inconel 600 using $\mathrm{Cu} / \mathrm{Ni}$ porous composite interlayer for gas pressure sensor application," Materials and Design, vol. 54, pp. 375-381, 2014.

[7] A. P. Xian, "Wetting of Si-Al-O-N ceramic by Sn-5at.\%Ti-X ternary active solder," Materials Science and Engineering: B, vol. 25, pp. 39-46, 1994.

[8] Y. H. Liu, J. D. Hu, P. Shen, X. H. Han, and J. C. Li, "Microstructural and mechanical properties of jointed $\mathrm{ZrO}_{2} / \mathrm{Ti}-6 \mathrm{Al}-4 \mathrm{~V}$ alloy using $\mathrm{Ti}_{33} \mathrm{Zr}_{17} \mathrm{Cu}_{50}$ amorphous brazing filler," Materials and Design, vol. 47, pp. 281-286, 2013.

[9] A. V. Durov, B. D. Kostjuk, A. V. Shevchenko, and Y. V. Naidich, "Joining of zirconia to metal with $\mathrm{Cu}-\mathrm{Ga}-\mathrm{Ti}$ and $\mathrm{Cu}-\mathrm{Sn}-\mathrm{Pb}-\mathrm{Ti}$ fillers," Materials Science and Engineering A, vol. 290, no. 1, pp. 186-189, 2000.

[10] M. Wu, C.-Z. Cao, R. Ud-Din, X.-B. He, and X.-H. Qu, “Brazing diamond/Cu composite to alumina using reactive $\mathrm{Ag}-\mathrm{Cu}-\mathrm{Ti}$ alloy," Transactions of Nonferrous Metals Society of China, vol. 23, no. 6, pp. 1701-1708, 2013.

[11] H. Ji, H. Chen, and M. Li, "Microstructures and properties of alumina/copper joints fabricated by ultrasonic-assisted brazing for replacing DBC in power electronics packaging," in Proceedings of the 15th International Conference on Electronic Packaging
Technology (ICEPT '14), pp. 1291-1294, Chengdu, China, August 2014.

[12] X. Chen, J. Yan, S. Ren, Q. Wang, J. Wei, and G. Fan, "Microstructure, mechanical properties, and bonding mechanism of ultrasonic-assisted brazed joints of $\mathrm{SiC}$ ceramics with $\mathrm{ZnAlMg}$ filler metals in air," Ceramics International, vol. 40, no. 1, pp. 683-689, 2014.

[13] W. Cui, J. Yan, Y. Dai, and D. Li, "Building a nano-crystalline $\alpha$-alumina layer at a liquid metal/sapphire interface by ultrasound," Ultrasonics Sonochemistry, vol. 22, pp. 108-112, 2015.

[14] R. Koleňák, P. Šebo, M. Provazník, M. Koleňáková, and K. Ulrich, "Shear strength and wettability of active Sn3.5Ag4Ti$(\mathrm{Ce}, \mathrm{Ga})$ solder on $\mathrm{Al}_{2} \mathrm{O}_{3}$ ceramics," Materials and Design, vol. 32, no. 7, pp. 3997-4003, 2011.

[15] S. Y. Chang, L. C. Tsao, M. J. Chiang, C. N. Tung, G. H. Pan, and T. H. Chuang, "Active soldering of indium tin oxide (ITO) with $\mathrm{Cu}$ in air using an $\mathrm{Sn3} .5 \mathrm{Ag} 4 \mathrm{Ti}(\mathrm{Ce}, \mathrm{Ga})$ filler," Journal of Materials Engineering and Performance, vol. 12, no. 4, pp. 383389, 2003.

[16] S. Y. Chang, T. H. Chuang, and C. L. Yang, "Low temperature bonding of alumina/alumina and alumina/copper in air using Sn3.5Ag4Ti(Ce,Ga) filler," Journal of Electronic Materials, vol. 36, no. 9, pp. 1193-1198, 2007.

[17] S. Y. Chang, T. H. Chuang, L. C. Tsao, C. L. Yang, and Z. $\mathrm{S}$. Yang, "Active soldering of $\mathrm{ZnS}-\mathrm{SiO}_{2}$ sputtering targets to copper backing plates using an $\mathrm{Sn} 3.5 \mathrm{Ag} 4 \mathrm{Ti}(\mathrm{Ce}, \mathrm{Ga})$ filler metal," Journal of Materials Processing Technology, vol. 202, no. 1-3, pp. 22-26, 2008.

[18] L. C. Tsao, "Direct active soldering of micro-arc oxidized Ti/ $\mathrm{Ti}$ joints in air using $\mathrm{Sn} 3.5 \mathrm{Ag} 0.5 \mathrm{Cu} 4 \mathrm{Ti}(\mathrm{RE})$ filler," Materials Science and Engineering A, vol. 565, pp. 63-71, 2013.

[19] T. H. Chuang, H. J. Lin, and C. C. Chi, "Rapid growth of tin whiskers on the surface of Sn-6.6Lu alloy," Scripta Materialia, vol. 56, no. 1, pp. 45-48, 2007.

[20] H. Hao, H. He, and Y. Lu, "Study of tin whisker growth accelerated by rare earth phase and the mechanism of tin whisker growth," in Proceedings of the15th International Conference on Electronic Packaging Technology (ICEPT '14), pp. 1120-1126, Chengdu, China, August 2014.

[21] T.-H. Chuang, "Temperature effects on the whiskers in rareearth doped Sn-3Ag-0.5Cu-0.5Ce solder joints," Metallurgical and Materials Transactions A: Physical Metallurgy and Materials Science, vol. 38, no. 5, pp. 1048-1055, 2007.

[22] M. Liu and A.-P. Xian, "Tin whisker growth on the surface of sn$0.7 \mathrm{Cu}$ lead-free solder with a rare earth $(\mathrm{Nd})$ addition," Journal of Electronic Materials, vol. 38, no. 11, pp. 2353-2361, 2009.

[23] T.-H. Chuang and H.-J. Lin, "Inhibition of whisker growth on the surface of Sn-3Ag-0.5Cu-0.5Ce solder alloyed with $\mathrm{Zn}$," Journal of Electronic Materials, vol. 38, no. 3, pp. 420-424, 2009.

[24] K. N. Tu, "Interdiffusion and reaction in bimetallic Cu-Sn thin films," Acta Metallurgica, vol. 21, no. 4, pp. 347-354, 1973.

[25] T.-H. Chuang, "Rapid whisker growth on the surface of Sn-3Ag$0.5 \mathrm{Cu}-1.0 \mathrm{Ce}$ solder joints," Scripta Materialia, vol. 55, no. 11, pp. 983-986, 2006.

[26] R. Kolenak, M. Chachula, P. Sebo, and M. Kolenakova, "Wettability and shear strength of active $\mathrm{Sn} 2 \mathrm{Ti}$ solder on $\mathrm{Al}_{2} \mathrm{O}_{3}$ ceramics," Soldering and Surface Mount Technology, vol. 23, no. 4, pp. 224-228, 2011.

[27] C. Peng, M. Chen, and S. Liu, "Die bonding of silicon and other materials with active solder," in Proceedings of the 11th International Conference on Electronic Packaging Technology \& 
High Density Packaging (ICEPT-HDP '10), pp. 275-278, IEEE, Xian, China, August 2010.

[28] R. Koleňák and M. Prach, "Research of joining graphite by use of active solder," Advanced Materials Research, vol. 875-877, pp. 1270-1274, 2014.

[29] L. Zhang, S.-B. Xue, L.-L. Gao et al., "Microstructure characterization of $\mathrm{SnAgCu}$ solder bearing Ce for electronic packaging," Microelectronic Engineering, vol. 88, no. 9, pp. 2848-2851, 2011.

[30] M. A. Dudek and N. Chawla, "Nanoindentation of rare earth$\mathrm{Sn}$ intermetallics in Pb-free solders," Intermetallics, vol. 18, no. 5, pp. 1016-1020, 2010.

[31] M. Pei and J. Qu, "Effect of lanthanum doping on the microstructure of tin-silver solder alloys," Journal of Electronic Materials, vol. 37, no. 3, pp. 331-338, 2008.

[32] M. Sadiq, R. Pesci, and M. Cherkaoui, "Impact of thermal aging on the microstructure evolution and mechanical properties of lanthanum-doped tin-silver-copper lead-free solders," Journal of Electronic Materials, vol. 42, no. 3, pp. 492-501, 2013.

[33] V. L. Lanin, "Physical effects of ultrasound in the liquid media and its applications in the technics," in Technology in the Electrotechnical Industry, vol. 2, pp. 10-15, 2013. 

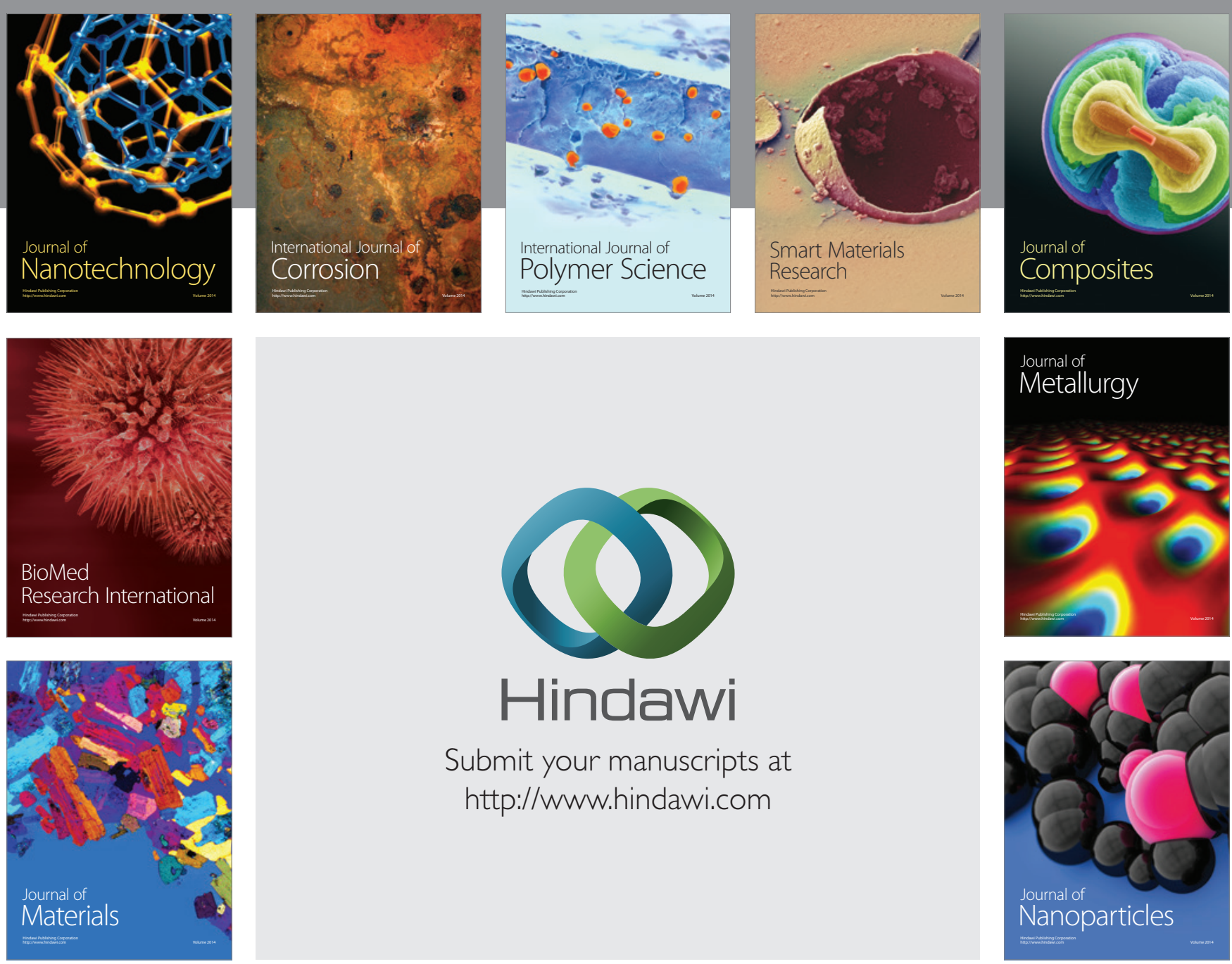

Submit your manuscripts at http://www.hindawi.com
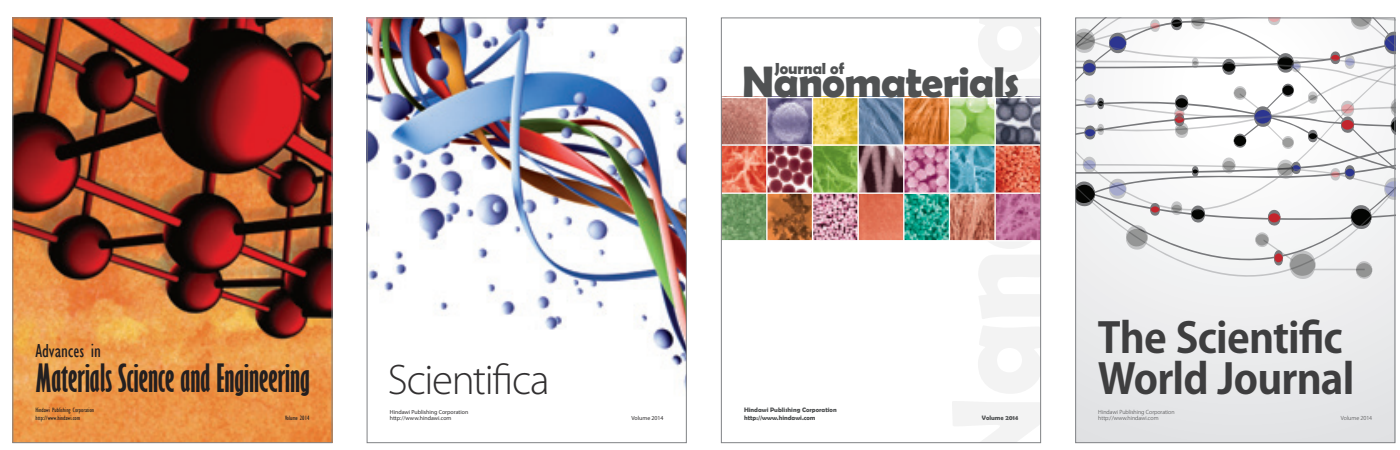

\section{The Scientific World Journal}
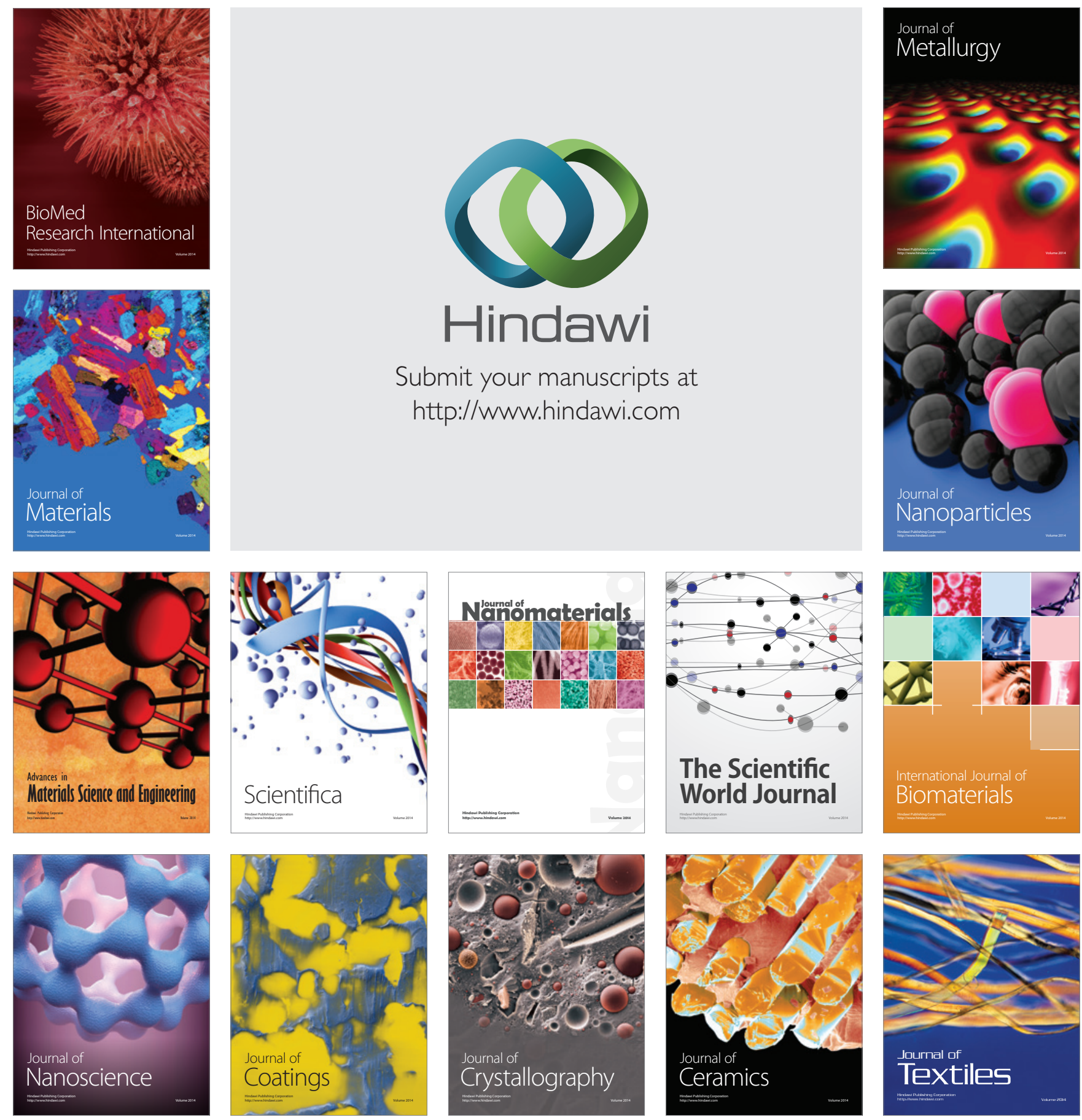